\title{
Satisfaction of users of full dentures with adhesive: A systematic review of the
} literature

\author{
Satisfação de usuários de próteses totais com adesivo: Uma revisão sistemática da literatura \\ Satisfacción de los usuarios de dentaduras postizas completas con adhesivo: Uma revisión
} sistemática de la literatura

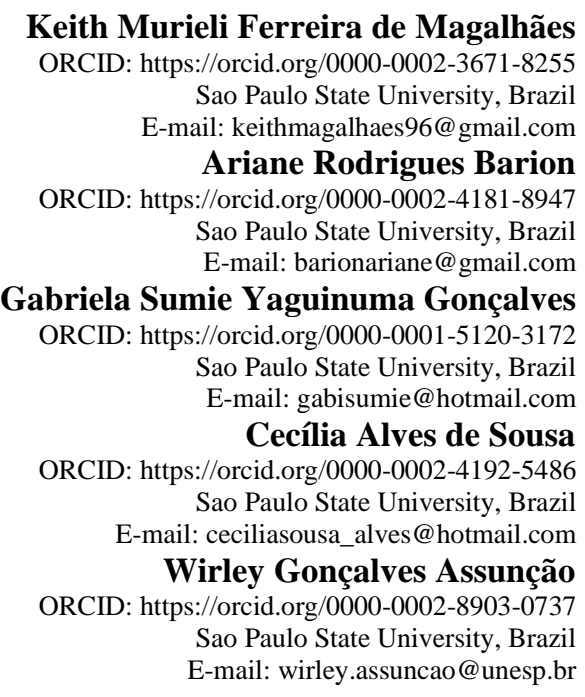

\begin{abstract}
Objective: To review the literature systematically in relation to the effectiveness of the adhesive for dental prostheses presented in terms of patient satisfaction and to evaluate the differences regarding the use or not of them. Methodology: A search was carried out in the databases PubMed / MEDLINE, Embase, Scopus and Web of Science according to the criteria of Preferred Reports for Systematic Reviews and Meta-Analysis. The PICO question was used to address the following specific question: "Patients who use adhesives on full denture satisfaction?". Results: Sixteen studies with a total of 1133 patients with age average of 67 years were included; in relation to masticatory capacity, improvement was found in feeding, increased vertical movement in the mandible and less intrusion of the prosthesis. As for satisfaction, studies have shown greater comfort, improvement in social, psychological, quality of life and oral health and self-confidence. No serious side effects have been reported and only oral adverse events have been coded. Conclusion: Although adhesives for dental prostheses do not improve their function, that is, they are not capable of problems related to anatomy or errors in the manufacture of the prosthesis, they affect as subjective evaluations of patients. The use of adhesives for prolonged complete dentures increases their retention and stability and positively affects the patient's satisfaction with regard to masticatory capacity, comfort and confidence, provided the recovery is adequate.
\end{abstract}

Keywords: Complete denture; Patient satisfaction; Denture adhesives; Questionnaire.

\section{Resumo}

Objetivo: Revisar a literatura sistematicamente em relação à eficácia do adesivo para próteses dentárias convencionais em termos de satisfação dos pacientes e avaliar as diferenças quanto à utilização ou não dos mesmos. Metodologia: Uma busca foi realizada nos bancos de dados PubMed/MEDLINE, Embase, Scopus e Web of Science de acordo com os critérios de Relatórios Preferidos para Revisões Sistemáticas e Meta-Análise. A questão PICO foi usada para abordar a seguinte questão específica: "Pacientes que utilizam adesivos em próteses totais apresentam maior satisfação?". Resultados: Dezesseis estudos com um total de 1133 pacientes com idade média de 67 anos foram incluídos; em relação à capacidade mastigatória, foi encontrada melhora na alimentação, aumento no movimento vertical na mandíbula e menor intrusão da prótese. Quanto à satisfação, estudos demonstraram maior conforto, melhora nos aspectos sociais, psicológicos, qualidade de vida e saúde bucal e autoconfiança. Não foram relatados 
efeitos colaterais graves e apenas eventos adversos orais foram codificados. Conclusão: Embora os adesivos para próteses dentárias não melhorem sua função, ou seja, não são capazes de resolver problemas relacionados à anatomia ou erros de confecção da prótese, eles afetam as avaliações subjetivas dos pacientes. O uso de adesivos para próteses totais convencionais aumenta significativamente sua retenção e estabilidade e afeta positivamente a satisfação do paciente quanto a capacidade mastigatória, conforto e confiança, desde que as mesmas estejam adequadas.

Palavras-chave: Prótese total; Satisfação do paciente; Adesivos para próteses dentárias; Questionário.

\section{Resumen}

Objetivo: Revisar la literatura de manera sistemática en relación a la efectividad del adhesivo para prótesis dentales presentada en términos de satisfacción del paciente y evaluar las diferencias en cuanto al uso o no de las mismas. Metodología: Se realizó una búsqueda en las bases de datos PubMed / MEDLINE, Embase, Scopus y Web of Science según los criterios de Preferred Reports para Revisiones Sistemáticas y Metanálisis. La pregunta PICO se utilizó para abordar la siguiente pregunta específica: "Pacientes que usan adhesivos para una completa satisfacción con la dentadura postiza?". Resultados: Se incluyeron 16 estudios con un total de 1133 pacientes con edad promedio de 67 años; en relación a la capacidad masticatoria, se encontró mejoría en la alimentación, mayor movimiento vertical en la mandíbula y menor intrusión de la prótesis. En cuanto a la satisfacción, los estudios han demostrado una mayor comodidad, mejora social, psicológica, calidad de vida y salud bucal y autoconfianza. No se han informado efectos secundarios graves y solo se han codificado los eventos adversos orales. Conclusión: Si bien los adhesivos para prótesis dentales no mejoran su función, es decir, no son capaces de presentar problemas relacionados con la anatomía o errores en la fabricación de la prótesis, inciden como evaluaciones subjetivas de los pacientes. El uso de adhesivos para prótesis completas prolongadas aumenta su retención y estabilidad e incide positivamente en la satisfacción del paciente en cuanto a capacidad masticatoria, comodidad y confianza, siempre que la recuperación sea adecuada.

Palabras clave: Dentadura total; Satisfacción del paciente; Adhesivos para prótesis dentales; Cuestionario.

\section{Introduction}

The literature indicates an increase in life expectancy of which, and although the rate of edentulism has fallen in recent years, there are still many countries with a large number of toothless patients who are undergoing treatment with complete dentures (Kumar et al., 2011). Despite technological advances and the evolution of implant dentistry, there are systemic contraindications and a cost-benefit ratio that does not allow the manufacture of prostheses on implants during rehabilitation planning (Marin et al., 2014). It should be noted that the absence of teeth, in addition to providing a change in masticatory efficiency, speech and aesthetics, also offers an imbalance in the stomatognathic system.

Thus, a correct adaptation between a total prosthesis and the adjacent mucosa is fundamental for the success of the rehabilitation treatment (Guimarães et al., 2018). However, it is common to find cases that present alveolar edges with great resorption, adapt in lesser support to support and maintain a conventional rehabilitation with total prosthesis (Spenciere et al., 2009), requiring the use of prosthetic adhesives to keep these prostheses in function and promote an improvement in adaptation, allowing correct masticatory efficiency, balanced distribution of tolerance and patient satisfaction.

Also known as removable denture holders, prosthetic adhesives were initially used in the late 18th century, but were mentioned in the dental literature in 1935, when the American Dental Association called it non-medicinal, along with the dental materials board (Yankell et al., 1984). In addition to provide adherence and retention of the total prosthesis to the oral mucosa, assist in stability, comfort, increase in masticatory activity and reduction in the accumulation of food under the denture (Nishi et al., 2020).

According to research, about $30 \%$ of denture users used adhesives at some point (Wilson et al., 1990; Coates et al., 2000; Koronis et al., 2012; Papadiochou et al., 2015). There are several commercially available forms, Grasso (Grasso et al., 2004) suggested that denture adhesives should be categorized into soluble and insoluble groups. The soluble category includes creams, powders and pastes, while the insoluble group consists of wafers and lozenges. In addition, based on their composition, denture adhesives can be divided into natural or synthetic denture adhesives. There is no consensus in the literature about one type of adhesive being better than another (Grasso et al., 2004; Guimarães et al., 2018). 
Self-perception studies report that when using prostheses with adhesive, comfort and satisfaction increased, thus improving OHRQoL (Oral Health-Related Quality of Life) (AlRumaih et al., 2018; Guimarães et al., 2018). However, there is a concern regarding the adverse effects of using adhesive for dental prosthesis, specifically changes in tissues and increased bone resorption (Psillakis et al., 2004). Some disadvantages such as irritation of the oral mucosa, changes in occlusal relationships, increased vertical dimension, increased alveolar bone loss, have been reported regarding the use of denture adhesives, especially insoluble ones, although without evidence (Nishi et al., 2020).

The aim of this article was to systematically review the literature regarding the effectiveness of the adhesive for conventional dental prostheses in terms of retention, stability and masticatory performance. And evaluate the differences regarding the use or not of dental prosthesis adhesives.

\section{Methods}

Inclusion criteria were: (1) English-language studies, (2) randomized controlled clinical trials (RCTs), (3) prospective studies, (4) clinical cases (5) with at least 10 patients. The exclusion criteria were: (1) in vitro studies, (2) retrospective studies, (3) reviews, (4) uncontrolled clinical cases, which had no direct comparison and with incomplete data that did not allow the collection of information.

The selection of articles was carried out by three independent reviewers previously calibrated (K.M.F.M, A.R.B, C.A.S). The authors conducted an electronic search on PubMed / MEDLINE, Scopus, Embase and Web of Science for articles published until February 2020 according to the eligibility criteria, using the following search terms "Total prosthesis, patient satisfaction and prosthetic patches total". The research strategy was as follows: ("denture, complete"[MeSH Terms] OR ("denture"[All Fields] AND "complete"[All Fields]) OR "complete denture"[All Fields] OR ("complete"[All Fields] AND "dentures"[All Fields]) OR "complete dentures"[All Fields]) AND ("patient satisfaction"[MeSH Terms] OR ("patient"[All Fields] AND "satisfaction"[All Fields]) OR "patient satisfaction"[All Fields]) AND ("dental cements"[MeSH Terms] OR ("dental"[All Fields] AND "cements"[All Fields]) OR "dental cements"[All Fields] OR ("denture"[All Fields] AND "adhesives"[All Fields]) OR "denture adhesives"[All Fields]). In addition, a manual search was carried out in the main journals in the area.

Initially, the articles were selected by title and abstract according to the pre-established eligibility criteria and all discrepancies in the searches carried out in the databases were analyzed by a fourth reviewer (W.G.A.) through a consensus meeting. Two authors (A.R.B., K.M.F.M) collected the relevant information from the articles and a third author (C.A.S.) reviewed all the information collected. The variables collected from the articles were: author / year, country, types of studies, number of patients, sex, average age, groups, location, follow-up, patch used, evaluation criteria, parameters used, advantages and results.

\section{Results}

\section{Literature Search}

A search of the selected databases found a total of 89 articles, including 25 from Pubmed, 19 from Embase, 30 Scopus and 15 from Web of Science. The application of the inclusion / exclusion criteria to the titles and abstracts of the selected comparative studies left 16 studies. Details on the search strategy are presented in the flowchart (shown in Fig. 1). 
Figure 1. Study design PRISMA.

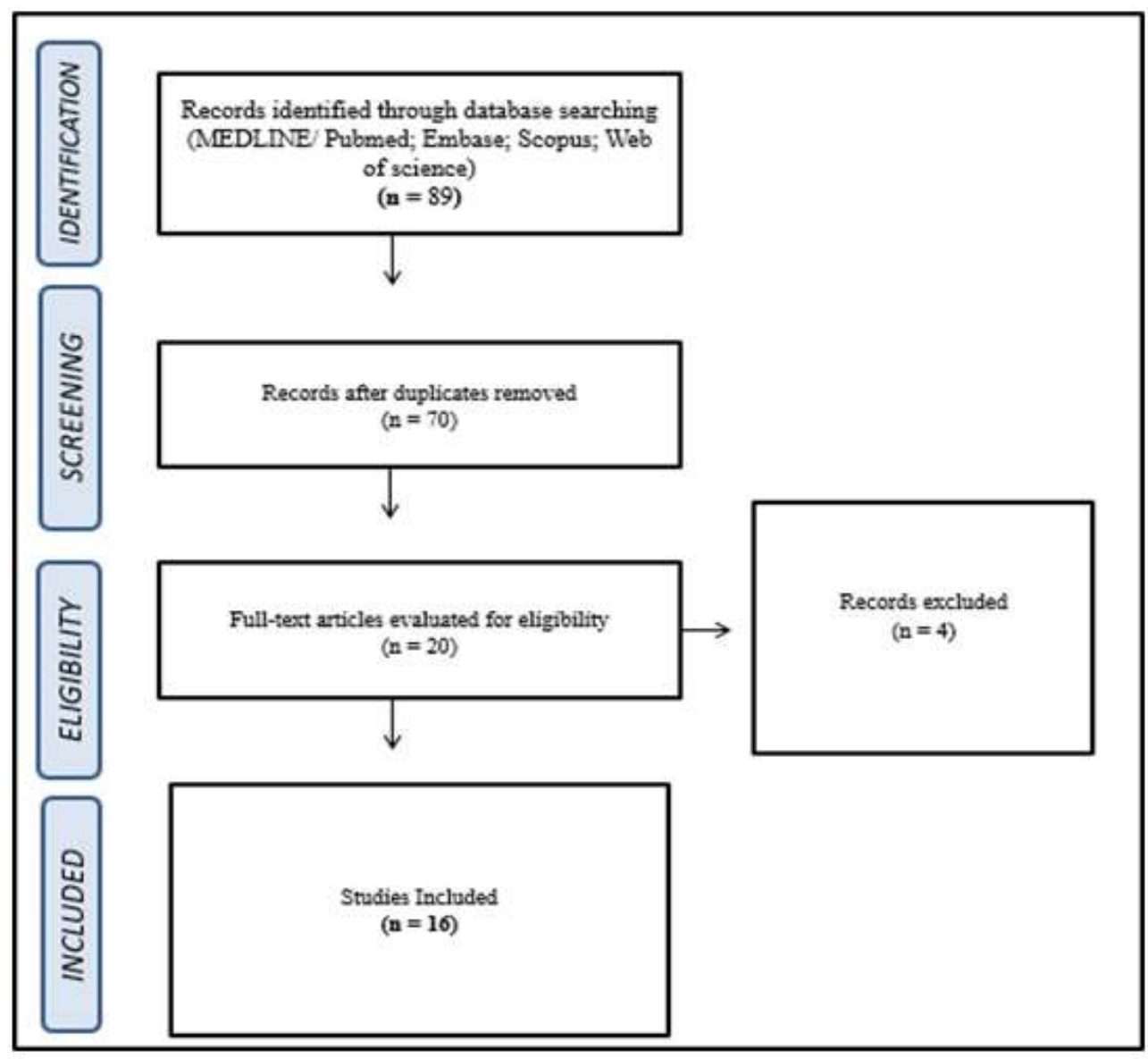

Source: Authors.

\section{Description of the studies}

Among these sixteen studies, ten were clinical cases and the other six were randomized clinical trials. They compared the author / year, country, types of studies, number of patients, sex, average age, groups, location, follow-up, patch used, evaluation criteria, parameters used, advantages and results (Table 1). 
Table 1. General data on the selected studies.

\begin{tabular}{|c|c|c|c|c|c|c|c|c|c|c|}
\hline Author/Year & Country & $\begin{array}{l}\text { Study } \\
\text { Design }\end{array}$ & Patients & Patient Selection & Sex & $\begin{array}{c}\text { Age } \\
\text { (years) }\end{array}$ & Groups & Study location & $\begin{array}{c}\text { Tests } \\
\text { performed }\end{array}$ & Follow up \\
\hline Bartelett/2013 & U.K. & $\begin{array}{l}\text { Clinical } \\
\text { Study }\end{array}$ & 35 & $\begin{array}{l}\text { Total prosthesis users } \\
\text { with up to } 7 \text { years of } \\
\text { use }\end{array}$ & $\begin{array}{l}13 \text { men, } \\
22 \\
\text { women }\end{array}$ & 73.9 & $\begin{array}{l}\text { There was no separation of } \\
\text { groups, all used the folder } \\
\text { Poligrip }{ }^{\circledR} \text { Denture Adhesive } \\
\text { Cream }\end{array}$ & Guy's Hospital & $\begin{array}{l}\text { NDNS and } \\
\text { OHPI Edent } \\
\text { questionnaires } \\
\text { and Wilcoxon } \\
\text { tests }\end{array}$ & 30 days \\
\hline Guimarães/2018 & Brazil & $\begin{array}{l}\text { Clinical } \\
\text { Study }\end{array}$ & 15 & Total prosthesis users & N.C. & N.C. & $\begin{array}{l}\text { Group with adhesive (Corega } \\
\text { Ultra) and without adhesive }\end{array}$ & $\begin{array}{l}\text { University of São Paulo - } \\
\text { Faculty of Dentistry }\end{array}$ & $\begin{array}{l}\text { Satisfaction } \\
\text { questionnaires } \\
\text { and GOHAI } \\
\text { tests }\end{array}$ & N.C. \\
\hline Hamad/ 2018 & $\begin{array}{l}\text { Saudi } \\
\text { Arabia }\end{array}$ & $\begin{array}{l}\text { Clinical } \\
\text { Study }\end{array}$ & 20 & $\begin{array}{l}\text { Toothless individuals } \\
\text { who accepted the } \\
\text { manufacture of new } \\
\text { complete dentures }\end{array}$ & $\begin{array}{l}11 \text { men, } 9 \\
\text { women }\end{array}$ & 68.20 & $\mathrm{MB}, \mathrm{HB}, \mathrm{MBA}$ and $\mathrm{HBA}$ & N.C. & Retention test & N.C. \\
\hline Koronis/2012 & Greece & $\begin{array}{l}\text { Clinical } \\
\text { Study }\end{array}$ & 30 & $\begin{array}{l}\text { Toothless individuals } \\
\text { who accepted the } \\
\text { manufacture of new } \\
\text { complete dentures }\end{array}$ & $\begin{array}{l}18 \text { men, } \\
12 \\
\text { women }\end{array}$ & 68.4 & $\begin{array}{l}\text { Unique group that should use } \\
\text { Fittydent } ® \text {, Protefix } ® \text { and } \\
\text { Seabond } ®\end{array}$ & Athens Dental School & $\begin{array}{l}\text { Satisfaction } \\
\text { Questionnaires }\end{array}$ & N.C. \\
\hline Kulak/2005 & Turkey & RCT & 30 & $\begin{array}{l}\text { Toothless individuals } \\
\text { with at least } 5 \text { years } \\
\text { of using complete } \\
\text { dentures. }\end{array}$ & $\begin{array}{l}14 \text { men, } \\
16 \\
\text { women }\end{array}$ & 62 & PVM-MA and CC & $\begin{array}{l}\text { University of Marmara in } \\
\text { Istanbul }\end{array}$ & $\begin{array}{l}\text { Test of } \\
\text { Wilcoxon }\end{array}$ & N.C. \\
\hline Marin/2014 & Brazil & RCT & 44 & $\begin{array}{l}\text { Toothless individuals } \\
\text { who accepted the } \\
\text { manufacture of new } \\
\text { complete dentures }\end{array}$ & $\begin{array}{l}14 \text { men, } \\
30 \\
\text { women }\end{array}$ & 64.8 & Protocol 1 and Protocol 2 & $\begin{array}{l}\text { Faculty of Dentistry of } \\
\text { Araraquara }\end{array}$ & $\begin{array}{l}\text { Satisfaction } \\
\text { questionnaires } \\
\text { and a } \\
\text { kinesiograph to } \\
\text { record } \\
\text { mandibular } \\
\text { movements }\end{array}$ & N.C. \\
\hline Munoz/2011 & $\begin{array}{l}\text { New } \\
\text { York }\end{array}$ & RCT & 37 & $\begin{array}{l}\text { Users of complete } \\
\text { and adjusted lower } \\
\text { complete dentures. }\end{array}$ & $\begin{array}{l}19 \text { men, } \\
18 \\
\text { women }\end{array}$ & 70.65 & $\begin{array}{l}\text { Adhesive-free, Cream not sold, } \\
\text { Super Poligrip® Free } \\
\text { and SuperPoligrip }{ }^{\circledR} \text { Strip }\end{array}$ & $\begin{array}{l}\text { University } \\
\text { at Buffalo School of Dental } \\
\text { Medicine }\end{array}$ & Index Kapur & N.C. \\
\hline Owhada/2019 & Tokyo & RCT & 200 & $\begin{array}{l}\text { Toothless individuals } \\
\text { who accepted the } \\
\text { manufacture of new } \\
\text { complete dentures }\end{array}$ & $\begin{array}{l}95 \text { men, } \\
105 \\
\text { women }\end{array}$ & 77 & $\begin{array}{l}\text { Cream Adhesive, Powder } \\
\text { Adhesive and Control Group }\end{array}$ & N.C. & $\begin{array}{l}\text { Visual Analog } \\
\text { Scale of } 10 \mathrm{~mm}\end{array}$ & N.C. \\
\hline Petersen/2019 & & Clinical & 200 & N.C. & N.C. & N.C. & N.C. & N.C. & N.C. & N.C. \\
\hline
\end{tabular}


Research, Society and Development, v. 10, n. 7, e5710716200, 2021

(CC BY 4.0) | ISSN 2525-3409 | DOI: http://dx.doi.org/10.33448/rsd-v10i7.16200

\begin{tabular}{|c|c|c|c|c|c|c|c|c|c|c|}
\hline & & Trial & & & & & & & & \\
\hline Pradíes/2009 & Spain & $\begin{array}{l}\text { Clinical } \\
\text { Study }\end{array}$ & 24 & $\begin{array}{l}\text { Total edentulous with } \\
\text { use of at least } 1 \text { year }\end{array}$ & N.C. & 58 & $\begin{array}{l}\text { Without adhesive, Control } \\
\text { adhesive and Experimental } \\
\text { adhesive }\end{array}$ & $\begin{array}{l}\text { Complutense University of } \\
\text { Madrid. }\end{array}$ & N.C. & 2 weeks \\
\hline Psikallis/2014 & $\begin{array}{l}\text { New } \\
\text { York }\end{array}$ & $\begin{array}{l}\text { Clinical } \\
\text { Study }\end{array}$ & 194 & $\begin{array}{l}\text { Users of bimaxillary } \\
\text { prostheses }\end{array}$ & $\begin{array}{l}77 \text { men, } \\
117 \\
\text { women }\end{array}$ & 66,6 & $\begin{array}{l}\text { Without adhesive and With } \\
\text { adhesive }\end{array}$ & Consultóriosparticulares & $\begin{array}{l}\text { Satisfaction and } \\
\text { test } \\
\text { questionnaires } \\
\text { using the } \\
\text { gnometer }\end{array}$ & N.C. \\
\hline Torres-Sanchez/2014 & Spain & RCT & 17 & $\begin{array}{l}\text { Users of complete } \\
\text { dentures, with } \\
\text { dentures installed } 2 \\
\text { months before the } \\
\text { study }\end{array}$ & $\begin{array}{l}6 \text { men, } 11 \\
\text { women }\end{array}$ & 51,41 & $\begin{array}{l}\text { Without adhesive (WA), with } \\
\text { adhesive A (AA) and with } \\
\text { adhesive B (BA) }\end{array}$ & $\begin{array}{l}\text { School of Dentistry at the } \\
\text { University of Seville }\end{array}$ & $\begin{array}{l}\text { Visual Analog } \\
\text { Scale of } 10 \mathrm{~mm}\end{array}$ & N.C. \\
\hline Kelsey/1997 & U.S.A. & $\begin{array}{l}\text { Clinical } \\
\text { Study }\end{array}$ & 25 & $\begin{array}{l}\text { Total toothless with } \\
\text { at least } 5 \text { years of } \\
\text { denture use. }\end{array}$ & $\begin{array}{l}13 \text { men, } \\
12 \\
\text { women }\end{array}$ & 65 & $\begin{array}{l}\text { Effergrip, Fixodent, Orafix, } \\
\text { Secure and Super PoliGrip. }\end{array}$ & University of Michigan & $\begin{array}{l}\text { Satisfaction } \\
\text { questionnaires }\end{array}$ & N.C. \\
\hline Uysal/ 1998 & Turkey & $\begin{array}{l}\text { Clinical } \\
\text { Study }\end{array}$ & 32 & Total toothless & $\begin{array}{l}14 \text { men, } \\
18 \\
\text { women }\end{array}$ & 61.47 & $\begin{array}{l}\text { Fittydent } \mathrm{I}^{\circledR} * \text {, Fittydent } \mathrm{II} \AA \text {, } \\
\text { Protefix }{ }^{\circledR} \text { and Seabond }{ }^{\circledR}\end{array}$ & $\begin{array}{l}\text { Hacettepe University at } \\
\text { Ankara }\end{array}$ & N.C. & N.C. \\
\hline Nishi/2019 & Japan & RCT & 200 & $\begin{array}{l}\text { Toothless individuals } \\
\text { who accepted the } \\
\text { manufacture of new } \\
\text { complete dentures }\end{array}$ & N.C. & 76,6 & $\begin{array}{l}\text { Control, Powder adhesive and } \\
\text { Cream adhesive }\end{array}$ & $\begin{array}{l}\text { Iwate Medical University, } \\
\text { Tohoku }\end{array}$ & $\begin{array}{l}\text { Visual Analog } \\
\text { Scale of } 10 \mathrm{~mm}\end{array}$ & 4 days \\
\hline Mañes/2011 & Spain & $\begin{array}{l}\text { Clinical } \\
\text { Study }\end{array}$ & 30 & $\begin{array}{l}\text { Patients using } \\
\text { removable full } \\
\text { dentures, regardless } \\
\text { of how long the } \\
\text { dentures were used or } \\
\text { the quality and } \\
\text { retention } \\
\text { performance }\end{array}$ & N.C. & N.C. & $\begin{array}{l}\text { Benfix } \AA \text {, Fittydent } \AA \text { and } \\
\text { Supercorega } \AA \text {. }\end{array}$ & N.C. & $\begin{array}{l}\text { Satisfaction } \\
\text { questionnaire } \\
\text { and a spring } \\
\text { scale for } \\
\text { measuring the } \\
\text { retention force } \\
\text { in grams }\end{array}$ & N.C. \\
\hline
\end{tabular}

N.C.: no reported. Source: Authors. 


\section{General data from included studies}

A total of 1133 patients with an average age of 67 years were included in the studies, they were individuals in which the total dentures already had a time of use or who accepted the manufacture of new dental prostheses. Most studies were conducted in universities (Kelsey et al., 1997; Uysal et al., 1998; Kulak et al., 2005; Pradíes et al., 2009; Koronis et al., 2012; Munoz et al., 2012; Bartlett et al., 2013; Marin et al., 2014; Guimarães et al., 2018; Torres-Sánchez et al., 2018; Ohwada et al., 2020) and only one in a private practice (Psillakis et al., 2004). Most studies included patients of both sexes (Kelsey et al., 1997; Uysal et al., 1998; Kulak et al., 2005; Pradíes et al., 2009; Munoz et al., 2012; Koronis et al., 2012; Bartlett et al., 2013; Ohwada et al., 2020). Eight studies randomly divided individuals into groups to compare different brands of adhesive and all selected studies assessed patient satisfaction using questionnaires and scales (Kelsey et al., 1997; Uysal et al., 1998; Psillakis et al., 2004; Kulak et al., 2005; Pradíes et al., 2009; Koronis et al., 2012; Munoz et al., 2012; Bartlett et al., 2013; Marin et al., 2014; Guimarães et al., 2018; Torres-Sánchez et al., 2018; Nishi et al., 2020; Ohwada et al., 2020). Most studies included patients who had less than 7 years of total prosthesis use (Kelsey et al., 1997; Uysal et al., 1998; Psillakis et al., 2004; Kulak et al., 2005; Pradíes et al., 2009; Mañes et al., 2011; Munoz et al., 2012; Bartlett et al., 2013; Guimarães et al., 2018; TorresSánchez et al., 2018; Ohwada et al., 2020) and five studies made new prostheses (Koronis et al., 2012; Marin et al., 2014; AlRumaih et al., 2017; Nishi et al., 2020; Ohwada et al., 2020). Most of the selected studies did not present enough data on the follow-up period of the selected individuals.

\section{Overall Satisfaction}

According to the assessment made by Guimaraes (Guimarães et al., 2018), 60\% of individuals reported comfort with the use of the patch, $67 \%$ reported improvement in social and psychological aspects, not needing to use medications to reduce discomfort and pain. The same had already been exposed by Bartllet (Bartllet et al., 2013) who observed an improvement in the quality of life and oral health. According to Koronis (Koronis et al., 2012), 65\% of individuals reported satisfaction in use and increased self-confidence for social activities. Likewise, in the study by Muñoz (Muñoz et al., 2012) patients rated comfort, confidence and satisfaction as significantly higher with the use of adhesive and also less movement (oscillation), just as Marin (Marin et al., 2014) obtained a result of general satisfaction statistically significant. Mañes (Mañes et al., 2011) (showed an increase in the satisfaction index for various functions of the prosthesis, the same was shown by Torres-Sanchez (Torres-Sanchez et al., 2018) in which patients satisfaction with the use of adhesives was significantly higher and the use of adhesives also prevented food to enter under the prosthesis, which would cause irritation and pain in the mucosa due to friction. Ohwada (Ohwada et al., 2020) did not show significant differences in the general satisfaction or in the Impact Profile on Oral Health in Toothless Patients and Nishi (Nishi et al., 2020) had as subjective result of the satisfaction index a value below the expected in the visual analog scale.

\section{Satisfaction Based on Adhesive Type}

As previously mentioned, Bartllet (Bartllet et al., 2013) reported improvement in eating behavior and chewing efficiency of patients who used the Poligrip Denture Adhesive Cream adhesive, implying an increase in the quality of life associated with oral health. Koronis (Koronis et al., 2012) showed Fittydent (pad type adhesive) as the preferred adhesive among patients, as well as the studies by Polyzois (Polyzois et al., 2012) and Mañes (Mañes et al., 2011), which also indicated participants' preference in favor of Fittydent. Uysal (Uysal et al., 1998), also evaluated cushion adhesives, among them Fittydent, showing positive results.

Marin (Marin et al., 2014) reported a high level of general satisfaction and altered jaw movements, with increased vertical movements of the jaw during chewing and less intrusion of the upper total dentures with the use of Ultra Corega 
Cream. While Muñoz (Muñoz et al., 2012) and Ohwada (Ohwada et al., 2020) reported greater confidence, comfort and satisfaction in the group with denture cream adhesive (Poligrip and GlaxoSmithKline). Still, chewing, retention, comfort and aesthetics significantly improved in the powder type adhesive group (Poligrip Powder and GlaxoSmithKline) in the study by Ohwada (Ohwada et al., 2020).

In the study by Torres-Sanchez (Torres-Sanchez et al., 2018), in which Fittydent and Corega GlaxoSmithKline were evaluated, the authors concluded that adhesives for complete dentures significantly improve patient satisfaction, as better retention, stability and less accumulation of food particles between the prosthesis and the mucosa compared to not using adhesives.

Kulak (Kulak et al., 2005) evaluated cream-type adhesives and reported improvement in the patient's subjective satisfaction levels, with the adhesive paste for dental prostheses based on the polymethylvinyl ether-maleic anhydride compound (PVM-MA) classified as superior. Psillakis (Psillakis et al., 2004) showed that patients reported improvement in the perception of prosthesis performance and comfort with the use of Fixodent cream adhesive.

This indicates that, among the participants who chose to use some adhesive for dentures, of those selected, most studies point the adhesive in the most comfortable, presenting the best results due to the social and psychological aspects, with increased confidence of the patient. patient, stability and retention of the prosthesis, improvement of oral health and quality of life, reduction of pain and discomfort, thus minimizing the need to use analgesic medications.

\section{Adhesive Removal}

According to Muñoz (Muñoz et al., 2012) while 14 (47\%) individuals considered the removal of the adhesive paste PVM - MA easy, 7 (23\%) considered it difficult. The removal of the adhesive paste CC was considered easy by 9 (30\%) and difficult by $17(57 \%)$ of the patients. There were no significant differences between the two adhesives in the removal of the prostheses $(\mathrm{p}=0.67)$. Koronis (Koronis et al., 2012) reported that Fittydent was considered the most difficult adhesive to remove from the prosthesis support area compared to Protefix and Seabond.

\section{Adverse events}

No serious adverse events have been reported and only oral adverse events have been coded. In the study by Koronis (Koronis et al., 2012), five patients reported several complaints related to the use of adhesive pad type, such as "difficulty" in adapting the size of the pillow to suit the prosthesis, "redness", "irritation" and "burning" ". In two cases, patients were unable to use any of the pillow brands. Specifically, one participant cannot use Fittydent $®$ cushions due to "thickness", while another cannot use Seabond $®$ cushions because they have caused "the desire to vomit".

\section{Discussion}

The most common type of rehabilitation in edentulous patients is still the installation of removable conventional full dentures. However, due to the limitations of the residual ridge, patients may encounter adaptation difficulties related to retention, comfort and masticatory efficiency. In order to provide the user with a better quality of life, emotional security and function, adhesives for complete dentures are indicated and pointed out as beneficial, as long as they are used properly (Weidner-Strahl et al., 1984; Adisman et al., 1989; Psillakis et al., 2004).

All evaluated studies observed an improvement in the stability of conventional full dentures when patients used the adhesive. Bartllet (Bartllet et al., 2013) reported an improvement in diet and patient satisfaction, however, he reported that it was not possible to identify whether it was the use of the patch or dietary advice. During the eligibility of individuals, patients who had been using conventional full dentures for some years were chosen, since new dentures may have ideal retention. The 
opposite was reported in the study by Guimarães (Guimarães et al., 2018), in which they observed that there was no statistically significant difference between individuals who used adhesive and placebo. However, toothless patients were selected who received new prostheses and completely adapted to the oral cavity, since this may have been a determining factor for the result.

It should be noted that the morphology of the residual bone crest can interfere with the results. AlRumaih (AlRumaih et al., 2018) reported that $80 \%$ of the patients had bone crest with more favorable conditions, vertical and horizontal resists, hamular notch, in the tori, buccal vestibule, having dimensions that facilitate the prosthesis retention, that is, the results can be alter in individuals with bone crest morphology that presents greater resorption. The same was observed by Kulak (Kulak et al., 2005) who, when comparing upper and lower residual edges, noticed that there was greater retention in upper prostheses. All of these results can be explained through the height and shape of the bone crest, because even with the application of the adhesive, retention and stability can be overloaded through the challenges of conventional full dentures (Kulak et al., 2005; Bartlett et al., 2013). All of these data can be evaluated through the Index Kapur, so that there is homogeneity in the individuals chosen for the elaboration of the research.

The percentages of people who did not find it difficult to remove the adhesive from the prostheses were slightly lower in the study by Uysal (Uysal et al., 1998) (compared to the study by Polyzois (Polyzois et al., 2012)). In addition, in the study by Uysal (Uysal et al., 1998), Fittydent ${ }^{\circledR}$ was the adhesive with a statistically significant preference, being more retentive and lasting, just as the study by Polyzois (Polyzois et al., 2012) also indicated participants' preference in favor of Fittydent ${ }^{\circledR}$ in regarding self-confidence in social activities.

Finally, in both studies, the participants' complaints included 'burning' and 'redness'. The results of the study by Mañes (Mañes et al., 2011) showed that all adhesives, regardless of the commercial brand involved, significantly improved retention in relation to the values of the group without adhesive, where the values found for median retention of prostheses in the absence of adhesive (control) were $58 \mathrm{~g}$, while Fittydent ${ }^{\circledR}$ reached $875 \mathrm{~g}$ and the other tested adhesives, Supercorega ${ }^{\circledR}$ and Benfix ${ }^{\circledR}$, produced intermediate forces $(491 \mathrm{~g}$ and $583 \mathrm{~g}$ respectively).

Ohwada (Ohwada et al., 2020) and Muñoz (Muñoz et al., 2012) carried out a cross-sectional study involving 3 types of adhesives for prostheses and no adhesives with well-fitted prostheses. They reported greater confidence, comfort and satisfaction in the group with denture cream adhesive. As these are cross-sectional studies, the same participants were used to assess conditions with and without denture adhesives, with a quantitative assessment of the use of denture adhesives. Several studies have classified participants according to the condition of their prostheses or supporting tissues. Uysal (Uysal et al., 1998) and Koronis (Koronis et al., 2012) used adhesive pads and both studies observed improvement in subjective evaluations when the prostheses or supporting tissues were in poor condition. Chewing improved significantly in the cream-type adhesive group, and chewing, retention, comfort and aesthetics significantly improved in the powder-type adhesive group (Ohwada et al., 2020). Kelsey (Kelsey et al., 1997) and Kulak (Kulak et al., 2005) evaluated cream-type adhesives using old dentures and both the studies reported improvement in the patient's subjective satisfaction levels in relation to the chewing capacity, comfort, retention and confidence as a result of the use of denture adhesives.

Prosthesis adhesives are available globally. Although they can be regulated differently in several countries, they are always available as consumer products. There are some precautions associated with the use of commercially available adhesives containing zinc, so it is important for consumers to follow the manufacturer's label instructions (Munoz et al., 2012). Dental professionals should play a key role in providing guidance to all patients with prostheses on use and the proper application of these products, taking the opportunity to explain to patients that, over time, their prostheses will need to be replaced (Felton et al., 2011). 


\section{Conclusion}

Despite all the positive results achieved by adhesives for conventional full dentures, it is important to note that patients need to be informed that adhesives should be used sparingly and educated to recognize that excessive use, in quantity or frequency of application, can be a sign that the dentures are out of order. Thus, patients should be warned that the prostheses must be replaced with new ones according to the wear and tear of their base.

Although adhesives for dental prostheses do not inevitably improve their function, that is, they are not able to solve problems related to anatomy or errors in making the prosthesis, they affect the subjective evaluations of patients. The use of adhesives for conventional full dentures significantly increases their retention and stability and positively affects patient satisfaction with regard to masticatory capacity, comfort and confidence, as long as they are adequate.

\section{References}

Adisman I. K. (1989). The use of denture adhesives as an aid to denture treatment. The Journal of prosthetic dentistry, 62(6), 711-715. https://doi.org/10.1016/0022-3913(89)90598-2

AlRumaih, H. S., AlHelal, A., Baba, N. Z., Goodacre, C. J., Al-Qahtani, A., \& Kattadiyil, M. T. (2018). Effects of denture adhesive on the retention of milled and heat-activated maxillary denture bases: A clinical study. The Journal of prosthetic dentistry, 120(3), 361-366. https://doi.org/10.1016/j.prosdent.2017.10.013

Bartlett, D. W., Maggio, B., Targett, D., Fenlon, M. R., \& Thomas, J. (2013). A preliminary investigation into the use of denture adhesives combined with dietary advice to improve diets in complete denture wearers. Journal of dentistry, 41(2), 143-147. https://doi.org/10.1016/j.jdent.2012.10.012

Coates A. J. (2000). Usage of denture adhesives. Journal of dentistry, 28(2), 137-140. https://doi.org/10.1016/s0300-5712(99)00046-9

Felton, D., Cooper, L., Duqum, I., Minsley, G., Guckes, A., Haug, S., Meredith, P., Solie, C., Avery, D., Deal Chandler, N., \& American College of Prosthodontists (2011). Evidence-based guidelines for the care and maintenance of complete dentures: a publication of the American College of Prosthodontists. Journal of prosthodontics: official journal of the American College of Prosthodontists, 20 Suppl 1, S1-S12. https://doi.org/10.1111/j.1532849X.2010.00683.X

Grasso J. E. (2004). Denture adhesives. Dental clinics of North America, 48(3), 721-vii. https://doi.org/10.1016/j.cden.2004.04.002

Guimarães, D. M., Marques, É. J., Almagro, G. C. D., Iegami, C. M., Stegun, R. C., Mukai, M. K.. (2018). Effect of Denture Adhesives in New Complete Dentures During a Function. The Open Dentistry Journal, 12, 969-73. doi: 10.2174/1874210601812010969.

Kanapka J. A. (1984). Bite force as a measure of denture adhesive efficacy. The Compendium of continuing education in dentistry, Suppl 4, S26-S30.

Kelsey, C. C., Lang, B. R., \& Wang, R. F. (1997). Examining patients' responses about the effectiveness of five denture adhesive pastes. Journal of the American Dental Association (1939), 128(11), 1532-1538. https://doi.org/10.14219/jada.archive.1997.0093

Koronis, S., Pizatos, E., Polyzois, G., \& Lagouvardos, P. (2012). Clinical evaluation of three denture cushion adhesives by complete denture wearers. Gerodontology, 29(2), e161-e169. https://doi.org/10.1111/j.1741-2358.2010.436.x

Kulak, Y., Ozcan, M., \& Arikan, A. (2005). Subjective assessment by patients of the efficiency of two denture adhesive pastes. Journal of prosthodontics: official journal of the American College of Prosthodontists, 14(4), 248-252. https://doi.org/10.1111/j.1532-849X.2005.00049.x

Kumar, M. S., \& Thombare, R. U. (2011). A comparative analysis of the effect of various denture adhesives available in market on the retentive ability of the maxillary denture: an in vivo study. Journal of Indian Prosthodontic Society, 11(2), 82-88. https://doi.org/10.1007/s13191-011-0067-8

Mañes, J. F., Selva, E. J., De-Barutell, A., \& Bouazza, K. (2011). Comparison of the retention strengths of three complete denture adhesives: an in vivo study. Medicina oral, patologia oral y cirugia bucal, 16(1), e132-e136. https://doi.org/10.4317/medoral.16.e132

Marin, D. O. M., Leite, A. R. P., Paleari, A. G., Rodriguez, L. S., Oliveira Junior, N. M., Pero, A. C., \& Compagnoni, M. A. (2014). Effect of a Denture Adhesive on the Satisfaction and Kinesiographic Parameters of Complete Denture Wearers: A Cross-Over Randomized Clinical Trial. Brazilian Dental Journal, 25(5), 391-398. https://doi.org/10.1590/0103-6440201302409

Munoz, C. A., Gendreau, L., Shanga, G., Magnuszewski, T., Fernandez, P., \& Durocher, J. (2012). A clinical study to evaluate denture adhesive use in wellfitting dentures. Journal of prosthodontics: official journal of the American College of Prosthodontists, 21(2), 123-129. https://doi.org/10.1111/j.1532849X.2011.00795.X

Nishi, Y., Nomura, T., Murakami, M., Kawai, Y., Nishimura, M., Kondo, H., Ito, Y., Tsuboi, A., Hong, G., Kimoto, S., Gunji, A., Suzuki, A., Ohwada, G., Minakuchi, S., Sato, Y., Suzuki, T., Kimoto, K., Hoshi, N., Saita, M., Yoneyama, Y., ... Hamada, T. (2020). Effect of denture adhesives on oral moisture: A multicenter randomized controlled trial. Journal of prosthodontic research, 64(3), 281-288. https://doi.org/10.1016/j.jpor.2019.08.004

Ohwada, G., Minakuchi, S., Sato, Y., Kondo, H., Nomura, T., Tsuboi, A., Hong, G., Itoh, Y., Kawai, Y., Kimoto, S., Gunji, A., Suzuki, A., Suzuki, T., Kimoto, K., Hoshi, N., Saita, M., Yoneyama, Y., Sato, Y., Morokuma, M., Okazaki, J., ... Hamada, T. (2020). Subjective Evaluation of Denture Adhesives: A Multicenter Randomized Controlled Trial. JDR clinical and translational research, 5(1), 50-61. https://doi.org/10.1177/2380084419837607 
Research, Society and Development, v. 10, n. 7, e5710716200, 2021

(CC BY 4.0) | ISSN 2525-3409 | DOI: http://dx.doi.org/10.33448/rsd-v10i7.16200

Papadiochou, S., Emmanouil, I., \& Papadiochos, I. (2015). Denture adhesives: a systematic review. The Journal of prosthetic dentistry, 113(5), 391-397.e2. https://doi.org/10.1016/j.prosdent.2014.11.001

Polyzois, G. L., \& de Baat, C. (2012). Attitudes and usage of denture adhesives by complete denture wearers: a survey in Greece and the Netherlands. Gerodontology, 29(2), e807-e814. https://doi.org/10.1111/j.1741-2358.2011.00566.x

Pradíes, G., Sanz, I., Evans, O., Martnez, F., \& Sanz, M. (2009). Clinical study comparing the efficacy of two denture adhesives in complete denture patients. The International journal of prosthodontics, 22(4), 361-367.

Psillakis, J. J., Wright, R. F., Grbic, J. T., \& Lamster, I. B. (2004). In practice evaluation of a denture adhesive using a gnathometer. Journal of prosthodontics: official journal of the American College of Prosthodontists, 13(4), 244-250. https://doi.org/10.1111/j.1532-849X.2004.04040.x

Spenciere, M. C. R. L., Zavanelli, A. C., Carvalho Júnior, H., Zavanelli, R. A. (2009). Impactof the use of adhesive strip over the satisfaction degree of institutionalized patients and wearers of convencional complete denture. Rev Odonto UNESP, 38(6):335-40.

Swartz, M. L., Norman, R. D., \& Phillips, R. W. (1967). A method for measuring retention of denture adherents: an in vivo study. The Journal of prosthetic dentistry, 17(5), 456-463. https://doi.org/10.1016/0022-3913(67)90143-6

Torres-Sánchez, C., Montoya-Salazar, V., Torres-Lagares, D., Gutierrez-Pérez, J. L., \& Jimenez-Castellanos, E. (2018). Satisfaction in complete denture wearers with and without adhesives: A randomized, crossover, double-blind clinical trial. Journal of clinical and experimental dentistry, 10(6), e585-e590. https://doi.org/10.4317/jced.54871

Uysal, H., Altay, O. T., Alparslan, N., \& Bilge, A. (1998). Comparison of four different denture cushion adhesives--a subjective study. Journal of oral rehabilitation, 25(3), 209-213. https://doi.org/10.1046/j.1365-2842.1998.00220.x

Weidner-Strahl S. K. (1984). Klinische Multicenter-Prüfung verschiedener Indikationen für Prothesen-Haftmittel [Clinical multicenter testing of various indications for denture adhesives]. Die Quintessenz, 35(8), 1547-1551.

Wilson, M. J., McCord, J. F., Watts, D. C. (1990). Denture adhesives: an in vitro evaluation. J Dent Res, 69:970.

Yankell S. L. (1984). Overview of research and literature on denture adhesives. The Compendium of continuing education in dentistry, Suppl 4, S18-S21. 